\section{JURNAL ABDIMAS

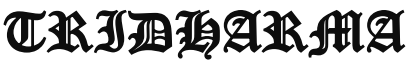

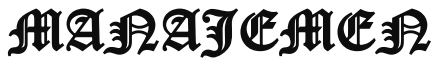

P-ISSN 2615-6849, E-ISSN 2716-070X

Jurnal ABDIMAS Vol. 1,No.2, Mei 2020,Hal(1-9)

@ Prodi Manajemen Fakultas Ekonomi Universitas Pamulang

Email: abdimasjurnal.unpam@gmail.com Telp: (021) 741-2566

\title{
SOSIALISASI DAN PELATIHAN E-LITIGASI DI LEMBAGA \\ BANTUAN HUKUM UNGGUL TANGERANG SELATAN GUNA MENINGKATKAN PROFESINALISME DALAM RANGKA PENDAMPINGAN MASYARAKAT PENCARI KEADILAN MELALUI APLIKASI KOMPUTER
}

\author{
Oksidelfa Yanto, Susanto, Yoyon M .Darusman, Bambang Wiyono, \\ Rizal S. Gueci \\ Dosen Magister Hukum Universitas Pamulang \\ Email dosen00240@unpam.ac.id, susanto@unpam.ac.id
}

\begin{abstract}
ABSTRAK
Tujuan dari pelaksanaan Pengabdian Kepada Masyarakat yang berjudul "Sosialisasi dan Pelatihan E-Litigasi di Lembaga Bantuan Hukum Unggul Tangerang Selatan Guna Meningkatkan Profesionalisme dalam Rangka Pendampingan Masyarakat Pencari Keadilan Melalui AplikasiKomputer" adalah sebagai upaya pemenuhan kewajiban Tri Dharma Perguruan Tinggi. Pengabdian Kepada Masyarakat dilakukan di LBH Unggul yang berdomisili kantor di Villa Pamulang Jl. Ismaya II Blok U 11 No 29 Pamulang, Tangerang Selatan, Banten pada tanggal 24 November 2019.

Berdasarkan hal di atas, kegiatan pengabdian kepada masyarakat dengan memberikan informasi dan atau tambahan pengetahuan mengenai sistem e-litigasidalam rangka mendukung penggunaan teknologi di Pengadilan merupakan suatu hal yang bermanfaat. sebagai wujud eksistensi Perguruan Tinggi yang bertujuan untuk memberikan konstribusi besar kepada pengembangan dan penerapan ilmu kepada masyarakat.

Metode yang digunakan pada Pengabdian Kepada Masyarakat ini berupa ekspositori yaitu penyampaian materi secara verbal dan inquiry yaitu pembelajaran yang menekankan pada proses berpikir kreatif kritis dan analitis terkait penggunaan sistem elitigasidalam peradilan cepat untuk menghindari pungutan liar serta peluang korupsi yang mungkin terjadi di Pengadilan.

Hasil Pengabdian Kepada Masyarakat yang diperoleh adalah beberapa pengacara yang tergabung dalam LBH Unggul sudah mulai mendaftarkan akun e-courtnya dan menambah pengetahuan dalam penggunaan fitur-fitur dalam sistem e-court dan elitigation.Kegiatan ini diharapkan mampu memberikan gambaran serta informasi berkaitan dengan cara penggunaan sistem e-litigation sebagai fasilitas berbasis teknologi
\end{abstract}




\section{JURNAL ABDIMAS

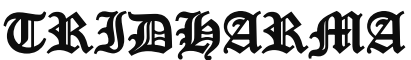

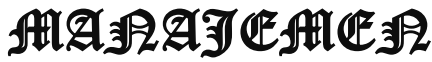

P-ISSN 2615-6849, E-ISSN 2716-070X

Jurnal ABDIMAS Vol. 1,No.2, Mei 2020,Hal(1-9)

@ Prodi Manajemen Fakultas Ekonomi Universitas Pamulang

Email: abdimasjurnal.unpam@gmail.com Telp: (021) 741-2566

dalam upaya pembayaran perkara serta birokrasi lainnya dengan basis online kepada pengacara di LBH agar dapat menyelesaikan kasus perkara lebih efisien dan cepat.

Kata Kunci : Pengabdian, E-Litigation, Pengadilan, Teknologi

\begin{abstract}
The purpose of the implementation of Community Service entitled "Socialization and E-Litigation Training at the South Tangerang Superior Legal Aid Institute To Improve Professionalism in the Framework of Facilitating Justice Seekers Through Computer Applications" is an effort to fulfill Tri Dharma College's obligations. Community Service is carried out at LBH Unggul which is domiciled in the office in Villa Pamulang Jl. Ismaya II Blok U 11 No 29 Pamulang, Tangerang Selatan, Banten on 24 November 2019.

Based on the foregoing, community service activities by providing information and or additional knowledge about the e-litigation system in the context of supporting the use of technology in the Court are beneficial. as a form of existence of Higher Education that aims to make a major contribution to the development and application of knowledge to the community.

The method used in this Community Service is expository namely the delivery of material verbally and inquiry that is learning that emphasizes the critical and analytical creative thinking process related to the use of e-litigation systems in quick justice to avoid illegal payments and opportunities for corruption that may occur in the Court.

The Community Service Results obtained are that several lawyers who are members of LBH Unggul have started to register their e-court accounts and increase knowledge in using features in the e-court and e-litigation systems.

This activity is expected to be able to provide an overview and information related to how to use the e-litigation system as a technology-based facility in case payment and other bureaucratic efforts on an online basis to lawyers at LBH in order to be able to resolve case cases more efficiently and quickly.
\end{abstract}

Keywords: Dedication, E-Litigation, Courts, Technology 


\section{JURNAL ABDIMAS

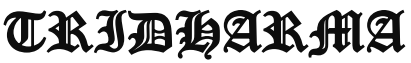

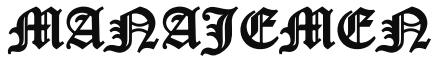

P-ISSN 2615-6849, E-ISSN 2716-070X

Jurnal ABDIMAS Vol. 1,No.2, Mei 2020,Hal(1-9)

@ Prodi Manajemen Fakultas Ekonomi Universitas Pamulang

Email: abdimasjurnal.unpam@ gmail.com Telp: (021) 741-2566

\section{PENDAHULUAN}

Lembaga Bantuan Hukum (LBHUNGGUL) sebagai mitra dalam pengabdian kepada masyarakat ini berlokasi di wilayah Tangerang Selatan, dimana Tangerang Selatan dianggap sebagai lokasi PKM yang cocok untuk diajukan, hal tersebut dikarenakan pada wilayah Tangerang Selatan terdapat banyak kasus-kasus yang berujung pada gugatan di Pengadilan seperti kasus sengketa tanah.

$$
\text { Wilayah tangerang selatan }
$$
dianggap sebagai wilayah yang langsung terdampak dari perkembangan kota Bumi Serpong Damai (BSD), dimana hal tersebut membuat harga dari tanah-tanah di pada wilayah tangerang selatan melonjak naik. Pengadilan Negeri Tangerang adalah pengadilan yang memiliki jarak terdekat dari tangerang selatan sehingga seringkali menjadi lokasi penyelesaian konflik pertanahan tersebut. Tingginya animo masyarakat tangerang Selatan untuk menyelesaikan sengketa di melalui jalur pengadilan, menjadi tantangan bagi Pengadilan untuk dapat melakukan pelayanan dengan baik salah satunya adalah dengan menerapkan Asas Peradilan yang Cepat, Sederhana dan Biaya Ringan. Asas Peradilan yang Cepat, Sederhana dan Biaya Ringan dapat berguna bukan hanya dalam hal efisiensi waktu dan hemat biaya melainkan juga untuk menghindari praktik judicial corruption. Praktik judicial corruption dianggap sebagai budaya dalam sistem birokrasi di Indonesia hal tersebut ditunjukan dengan Suap, Gratifikasi dan lain-lain sehingga membuat disparitas keadilan antara para pencari keadilan.

Praktek korupsi yang terjadi di lembaga peradilan (judicial corruption) di Indonesia saat sekarang ini dinilai sedemikian kronis kondisinya. Demikian kronisnya, sehingga bilamana diibaratkan sebagai suatu penyakit boleh dikatakan sudah memasuki tahap stadium empat. Karena, praktek korupsi di lembaga peradilan secara sistemik telah melibatkan semua aktor didalamnya mulai dari polisi, jaksa,hakim dan panitera, bahkan terjadi di semua tingkatan, juga melibatkan pengacara dan masyarakat pencari keadilan itu sendiri. Korupsi telah menjadi realita massif, sistemik dan struktural. Di kalangan praktisi hukum seolah-olah telah tumbuh sikap semakin permisif terhadap praktik judicial corruption.

Dianggap sebagai sesuatu yang memang biasa dilakukan, bahkan harus dilakukan, atau terpaksa harus dilakukan (bussines as an usual). Memang praktik peradilan yang buruk sedemikian itu tidak dapat digeneralisir. Kalangan advokat yang takut perkara kliennya nanti akan dikalahkan, cenderung berusaha 


\section{JURNAL ABDIMAS

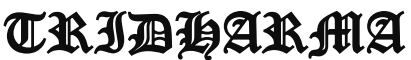

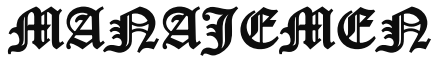

P-ISSN 2615-6849, E-ISSN 2716-070X

Jurnal ABDIMAS Vol. 1,No.2, Mei 2020,Hal(1-9)

@ Prodi Manajemen Fakultas Ekonomi Universitas Pamulang

Email: abdimasjurnal.unpam@ gmail.com Telp: (021) 741-2566 melakukan segala cara untuk memenangkan perkara. Undang-Undang Kekuasaan Kehakiman menggariskan sebuah ketentuan bahwa pengadilan harus membantu pencari keadilan dan berusaha mengatasi segala hambatan dan rintangan untuk dapat tercapainya peradilan yang sederhana, cepat dan biaya ringan. Ketentuan ini Sistem administrasi peradilan telah diterapkan (manajemen kasus yang efektif dan efektif). Mahkamah Agung Republik Indonesia Rencana reformasi peradilan sedang berlangsung pada 2010-2035 agenda agenda untuk program reformasi Pandangan yang sangat bagus tentang kekuatan keadilan (baca: Mahkamah Agung).

Modernisasi manajemen kasus terkait erat dengan renovasi Teknologi informasi,salah satu fitur pemulihan domain bantuan.Atas hal tersebutlah maka sistem E-Litigasi mulai di perkenalkan guna tercapainya peradilan yang sederhana, cepat dan biaya ringan dan moderenisasi manajemen kasus di masing-masing Pengadilan yang di harapkan dapat memberikan berbagai keuntungan yaitu kecepatan (speed), konsistensi (consistency), ketepatan (precision), dan keandalan (reliability), hal tersebut mengingat terdapat beberapa problematika khas yang menjadi kebiasaan dalam sistem pengadilan yakni penangan perkara yang lambat, sulit diakses hingga pada titik integritas para aparatur di dalamnya, dan kesemua hal tersebut selain menjadi momok dalam di berbagai pengadilan juga menjadi problematika yang menghinggapi Mahkamah Agung (MA).Maka dalam hal ini tema yang akan di angkat buka sekedar majelis hakim perlu menerapkan konsep social justice yang bermuara pada keadilan retributif, yakni memeriksa, menuntut, dan memutus perkara dengan mengedepankan rasa keadilan, namun lebih dari itu dimana. Sementara penerapan e-litigasi akan memperluas cakupan pemanfaatan sistem sidang elektronik.

Sebelumnya, e-court sudah digunakan untuk pendaftaran perkara, pembayaran biaya perkara, dan biaya pemanggilan. Kini, kegiatan jawabmenjawab, pembuktian, dan penyampaian putusan juga diterapkan. Selain itu, penerapan e-litigasi memperluas cakupan pemanfaatan layanan peradilan. Dengan e-litigasi, para advokat, biro hukum, jaksa selaku pengacara negara, dan in house lawyer yang ditunjuk badan hukum serta kuasa insidentil yang memenuhi syarat sebagai pengguna sistem informasi peradilan bisa mudah menjalani proses persidangan dan memantau litigasi untuk persidangan di tingkat pertama juga diikuti dengan pemanfaatan e-court untuk 


\section{JURNAL ABDIMAS

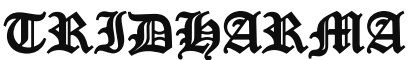

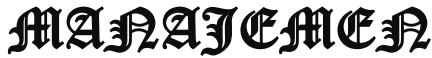

P-ISSN 2615-6849, E-ISSN 2716-070X

Jurnal ABDIMAS Vol. 1,No.2, Mei 2020,Hal(1-9)

@ Prodi Manajemen Fakultas Ekonomi Universitas Pamulang

Email: abdimasjurnal.unpam@gmail.com Telp: (021) 741-2566 upaya hukum banding kasasi dan peninjauan kembali terhadap perkara yang menggunakan e-litigasi pada tingkat pertama. Berdasarkan latar belakang masalah tersebut maka tim Pengabdian Kepada Masyarakat melakukan penyuluhan dengan judul "Sosialisasi dan Pelatihan E-Litigasi di Lembaga Bantuan Hukum Unggul Tangerang Selatan Guna Meningkatkan Profesionalisme dalam Rangka Pendampingan Masyarakat Pencari Keadilan Melalui Aplikasi Komputer"

\section{RUMUSAN MASALAH}

Berdasarkan latar belakang diatas dapat dirumusan permasalah dalam pelaksanaan pengabdian masyarakat bagi nelayan kepulauan seribu sebagai berikut: 1.Mengapa advokat wajib mendaftarkan akun e-litigasi dalam penyelesaian kasus di Persidangan?

2.Bagaimana cara penggunaan sistem elitigasi?

\section{TUJUAN PELAKSANAAN}

Tujuan pelaksanaan pengabidian msyarakat di LBH Unggul adalah:

3.Meningkatkan kemampuan advokat dalam menggunakan akun e-litigasi yang dilakukan oleh advokat
4.Memberikan pengarahan kepada advokat tentang cara penggunaan elitigasi dalam penyelesaian kasus di Pengadilan.

\section{TINJAUAN PUSTAKA}

\section{Lembaga Bantuan Hukum}

LBH merupakan sebuah lembaga yang non profit, lembaga bantuan hukum ini didirikan dengan tujuan memberikan pelayanan bantuan hukum secara gratis (cuma-cuma) kepada masyarakat yang membutuhkan bantuan hukum, namun tidak mampu, buta hukum dan tertindas, arti cuma-cuma yaitu tidak perlu membayar biaya (fee) untuk pengacara, tapi untuk biaya operasional seperti biaya perkara di pengadilan (apabila kasus sampai ke pengadilan) itu ditanggung oleh si klien, itupun kalau klien mampu. Tetapi biasanya LBH-LBH memiliki kekhususan masing-masing dalam memilih kasus yang akan ditanganinya sesuai dengan visi-misinya.

\section{Pengertian E-Litigasi}

Peraturan Mahkamah Agung Nomor 1 Tahun 2019 tentang Administrasi Perkara dan Persidangan di Pengadilan Secara Elektronik memerlukan petunjuk teknis untuk memudahkan pemahaman dalam memberikan pelayanan administrasi perkara dan persidangan di pengadilan. 


\section{JURNAL ABDIMAS

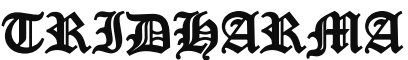

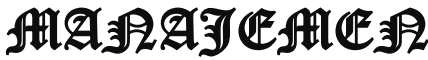

P-ISSN 2615-6849, E-ISSN 2716-070X

Jurnal ABDIMAS Vol. 1,No.2, Mei 2020,Hal(1-9)

@ Prodi Manajemen Fakultas Ekonomi Universitas Pamulang

Email: abdimasjurnal.unpam@gmail.com Telp: (021) 741-2566
Peradilan dilakukan dengan sederhana, cepat dan biaya ringan sesuai dengan Pasal 2 ayat (4) Undang-Undang Nomor 48 Tahun 2009.Tuntutan dan perkembangan zaman, mengharuskan adanya pelayanan administrasi perkara dan persidangan di pengadilan yang lebih efektif dan efisien.

Ketentuan Peraturan Mahkamah Agung Nomor 3 Tahun 2018 tentang Administrasi Perkara di Pengadilan Secara Elektronik perlu disempurnakanPeraturan ini dimaksudkan sebagai landasan hukum penyelenggaraan administrasi perkara dan persidangan secara elektronik di pengadilan untuk mendukung terwujudnya tertib administrasi perkara yang profesional, transparan, akuntabel, efektif, efisien dan modern. Untuk saat ini pengguna yangdapat mencicipi layanan Aplikasi $E$ Court hanya terbatas untuk kalangan Advokatsaja, dan akan diatur kemudian untuk pengguna perorangan maupun Badan Hukum

Selain itu hal ini juga dimaksudkan untuk mengelola kebutuhan edukasi dansosialisasi dalam rangka migrasi sistem manual ke elektronik (digitalisasi). Penggunaterdaftar yang dalam hal ini merupakan Advokat diharapkan dapat lebih siap untukmerespon dan membiasakan diri dengan penggunaan aplikasi ini sebagai bagian darimanajemen perubahan yang bertahap pada bidang manajemen perkara dari sistemmanual ke elektronik.

\section{METODE PELAKSANAAN}

Metode kegiatan ini berupa sosialisasi Dan Pelatihan Penggunaan Aplikasi E-Court,berikut ini adalah tahapan pelatihan yang dilakukan:

\section{Tahap Persiapan}

Tahap persiapan yang dilakukan meliputi: a. Survey awal, pada tahap ini dilakukan survei ke lokasi Kantor Sekretariat LBH Unggul di Jl. Ismaya II, Tangerang Selatan

b. Pemantapan dan penentuan lokasi dan sasaran. Setelah survey maka ditentukan lokasi pelaksanaan dan sasaran peserta kegiatan.

c. Penyusunan bahan/materi sosialisasi penggunaan aplikasi elitigation.

2. Tahap Pelaksanaan Penelitian

Tahap ini akan diberikan penjelasan mengenai cara penggunaan aplikasi elitigation.

\section{Tahap Penyuluhan}

Untuk melaksanakan kegiatan tersebut digunakan beberapa metode penyuluhan yaitu:

a. Metode Ceramah

Metode ceramah dipilih untuk memberikan penjelasan tentang 


\section{JURNAL ABDIMAS

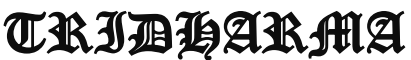

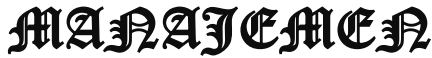

P-ISSN 2615-6849, E-ISSN 2716-070X

Jurnal ABDIMAS Vol. 1,No.2, Mei 2020,Hal(1-9)

@ Prodi Manajemen Fakultas Ekonomi Universitas Pamulang

Email: abdimasjurnal.unpam@gmail.com Telp: (021) 741-2566 pentingnya mendaftarkan akun elitigation dalam penyelesaian perkara di Persidangan.

b. Metode Tanya Jawab

Metode Tanya jawab sangat penting bagi para peserta pelatihan. Metode ini memungkinkan para peserta menggali pengetahuan sebanyak-banyaknya tentang cara penggunaan aplikasi elitigation.

c. Metode Simulasi

Metode simulasi ini diberikan kepada para peserta penyuluhan dengan memberikan contoh pendaftaran akun elitigation dan menunjukan fitur-fitur yang terdapat dalam aplikasi e-litigation.

\section{HASIL DAN PEMBAHASAN}

Pengabdian Masyarakat yang diselenggarakan pada tanggal 14 November 2019 sampai dengan 16 November 2019 yang dilakukan oleh dosen-dosen Universitas Pamulang yaitu Dr. Oksidelfa Yanto, S.H., H., Dr. Susanto, S.H., M.M., M.H., Dr. Yoyon M. Darusman, S.H., M.M., Dr. Bambang Wiyono, S.H., M.H., dan Dr. Rizal S. Gueci, S.H., MIC.berjalan dengan lancar dan mendapat antusias dari anggota LBH Unggul Tangerang Selatan tersebut para dosen memberikan penjelasan tentang tentang e-litigasi yang wajib diketahui oleh para advokat termasuk advokat yang bernaung di LBH Unggul.

System e-court diluncurkan dalam rangka memnuhi asas peradilan cepat, sederhana dan biaya ringan. Dalam e-litigasi ini advokat tidak perlu dating ke pengadilan dalam persidangan. E-litigasi ini akan disepakati pada saat siding pertama setelah para pihak lengkap.

Proses persidangan e-litigasi ini ada pada proses jawab jinawab (memberikan jawaban, replik, duplik) sedangkan pada tahap persidangan pembuktian para pihak hadir dalam persidangan.

\section{KESIMPULAN DAN SARAN}

\section{Kesimpulan}

Berdasarkan hasil pelaksanaan kegiatan pengabdian kepada masyarakat oleh Lembaga Penelitian dan Pengabdian Masyarakat (LPPM) dan Dosen Program Studi Magister Hukum Universitas Pamulang lembaga LBH Unggul adalah sebagai berikut:

1. Setiap advokat yang menyelesaikan kasus hukum di Pengadilan wajib memiliki akun e-court agar penyelesian perkara lebih efisien dan mampu mengaplikasikan system elitigation.

2. Cara penggunaan aplikasi e-court dan e-litigation sederhana, ikuti langkah 


\section{JURNAL ABDIMAS

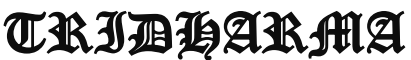

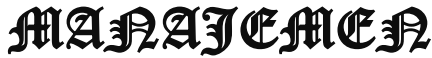

P-ISSN 2615-6849, E-ISSN 2716-070X

Jurnal ABDIMAS Vol. 1,No.2, Mei 2020,Hal(1-9)

@ Prodi Manajemen Fakultas Ekonomi Universitas Pamulang

Email: abdimasjurnal.unpam@ gmail.com Telp: (021) 741-2566 atau tahapan yang diperlukan yang berada dalam fitur aplikasi tersebut.

Dalam konteks manajemen administrasi di pengadilan, keberadaan elitigasi dinilai akan membantu dalam mempermudah masyarakat dalam hal pendaftarkan perkara di persidangan, sebagai dampak positif pelayanan berbasis online.

Terdapat 5 ketentuan baru yang diatur dalam Petunjuk Teknis ini:

1.Upaya Hukum Secara Elektronik adalah pengajuan upaya hukum sebagaimana ketentuan peraturan perundang-undangan dengan mempergunakan Aplikasi eCourt.

2.Calon Pengguna Terdaftar adalah setiap orang yang akan melakukan Pendaftaran pada Aplikasi e-Court.

3.Aplikasi pendukung Tatakelola

Administrasi Perkara: Monitoring

Implementasi SIPP (MIS), Evaluasi

Implementasi SIPP (EIS), Sistem

Informasi Manajemen Tatalaksana

Perkara (SIMTALAK), E-Register, E-

Keuangan

4.Pelayanan Terpadu Satu Pintu selanjutnya disingkat PTSP.

5.Meja e-Court adalah salah satu bentuk pelayanan yang membantu para pihak yang menggunakan administrasi perkara dan persidangan secara elektronik.

Persyaratan sebagai Pengguna Lain:
1. Perorangan harus memiliki: Kartu Tanda Penduduk dan/atau Surat Keterangan pengganti KTP; atau Passport;

2. Kementerian dan Lembaga/BUMN atau Badan Usaha lain milik pemerintah harus memiliki: Kartu Tanda Penduduk atau Surat Keterangan pengganti KTP, Kartu Pegawai, dan Surat Kuasa/Surat Tugas.

3. Kejaksaan sebagai Pengacara Negara harus memiliki: Kartu Tanda Penduduk atau Surat Keterangan pengganti KTP; Kartu Pegawai; dan Surat Kuasa dan/atau Surat Tugas.

4. Badan Hukum harus memiliki: Kartu Tanda Penduduk atau Surat Keterangan pengganti KTP, Surat Keputusan sebagai Karyawan; dan Surat Kuasa Khusus.

Kuasa Insidentil harus memiliki:

Kartu Tanda Penduduk atau Surat Keterangan pengganti KTP, Surat Kuasa Khusus, Ijin Insidentil dari Ketua Pengadilan.

\section{Saran}

Berdasarkan hasil kesimpulan didapatkan beberapa saran sebagai berikut:

1.Untuk meningkatkan ketertarikan advokat untuk mendaftarkan akun e-court dalam penyelesaian perkara, sebaiknya ditambahkan dan atau ditingkatkan fiturfitur lainnya yang mendukung 


\section{JURNAL ABDIMAS

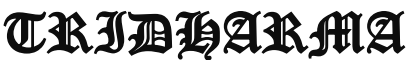 \\ AIA}

P-ISSN 2615-6849, E-ISSN 2716-070X

Jurnal ABDIMAS Vol. 1,No.2, Mei 2020,Hal(1-9)

@Prodi Manajemen Fakultas Ekonomi Universitas Pamulang

Email: abdimasjurnal.unpam@gmail.com Telp: (021) 741-2566 kemudahan dan efisiensi penggunakan aplikasi tersebut.

2.Kemudahan akses menjadi hal yang perlu ditingkatkan berkaitan dengan upaya mendukung teknologi dalam hal penyelesaian perkara di Pengadilan

\section{DAFTAR PUSTAKA.}

Krisnaldy,,Gos Ishak (2018). Manajemen wajtu dalam penggunaan gadget dan alat komunikasi era saat ini Jurnal Pengabdian Dharma Laksana, 1(2), 150160.

Maddinsyah, A., Fauzi, I., \& Barsah, A. (2019). Peran Teknologi Dalam Mengembangkan Potensi Diri Bagi Santri Di Yayasan Pembangunan Masyarakat Sejahtera Kelurahan Kedaung Pamulang Tangerang Selatam-Banten. Jurnal Pengabdian Dharma Laksana, 1(2), 259266.

Nurwita, N., Susanti, F., Permada, D. N. R., \& Oktrima, B. (2020). DAMPAK BURUK PEMAKAIAN MEDIA SOSIAL TERHADAP SEMANGAT DAN CAPAIAN BELAJAR SISWA SMP ARRAISIYAH

PAMULANG". Jurnal ABDIMAS, l(1).

Qurbani, D., Oktrima, B., \& Tanjung, A. W. (2019). MENDIDIK DAN
MENGAJARKAN ANAK UNTUK

MENGENAL ALLAH PADA USIA DINI DENGAN METODE STORY TELLING DI TK AL-HIDAYAH PAMULANG, TANGERANG SELATAN. Jurnal Pengabdian Dharma Laksana, 1(2), 228-239

Sina, I., Maryunani, B. J., \& Harahab, N. (2017). Analysis of total economic value of ecosystem mangrove forest in the coastal zone Pulokerto Village District of Kraton Pasuruan Regency. International Journal of Ecosystem, 7(1), 1-10.

Susanto, S., \& Iqbal, M. (2019). Pengabdian Kepada Masyarakat Dalam Sinergitas Akademisi Dan TNI Bersama Tangkal Hoax Dan Black Campaign. CARADDE: Jurnal Pengabdian Kepada Masyarakat, 2(1).

Susanto, S., Sarwani, S., \& Afandi, S. (2018). Analisis Kinerja Keuangan Untuk Mengetahui Tingkat Kesehatan, Pertumbuhan Dan Prospek Usaha Pada Unit Usaha Koperasi (Studi Kasus Koperasi Awak Pesawat Garuda Indonesia di Tangerang). INOVASI, 1(1).

Susanto, S., \& Iqbal, M. (2019). Pengabdian Kepada Masyarakat Dalam Sinergitas Akademisi Dan TNI Bersama Tangkal Hoax Dan Black Campaign. 


\begin{tabular}{|c|c|}
\hline JURNAL ABDIMAS & P-ISSN 2615-6849 , E-ISSN 2716-070X \\
\hline 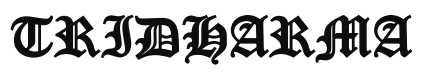 & Jurnal ABDIMAS Vol. 1,No.2, Mei 2020,Hal(1-9) \\
\hline 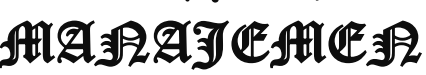 & Email: abdimasjurnal.unpam@ @mail.com Telp: (021) 741-2566 \\
\hline
\end{tabular}

CARADDE: Jurnal Pengabdian Kepada Masyarakat, 2(1).

Pasaribu, V. L. D., Agrasadya, A., Shabrina, N., \& Krisnaldy, K. (2020). MENJADI ENTERPRENEUR MUDA YANG MEMILIKI JIWA LEADERSHIP UNTUK MENGHADAPI MASA DEPAN. Abdi Laksana, 1(1)

Pasaribu, V. L. D., Elburdah, R. P., Sudarso, E., \& Fauziah, G. (2020). PENGGUNAAN MANAJEMEN WAKTU TERHADAP PENINGKATAN PRESTASI BELAJAR DI SMP ARAISIYAH. Jurnal ABDIMAS, 1(1)

Pasaribu, V. L. D., Susanti, F., \& Hartuti, E. T. K. (2019). MEMOTIVASI SISWA DAN SISWI SMK LETRIS INDONESIA DI DALAM MENENTUKAN PILIHAN UNTUK MELANJUTKAN PENDIDIKAN ATAU BEKERJA SETELAH LULUS SEKOLAH. Jurnal Pengabdian Dharma Laksana, 1(2), 161-172.

Zulfitra, Z., Susanto, S., Mubarok, A., Sutoro, M., \& Anwar, S. (2019). Manajemen Bisnis Sebagai Sarana Untuk Menumbuhkan Pengusaha-Pengusaha Baru (Studi Kasus pada PKBM Nurul Qolbi, Kota Bekasi, Jawa Barat). Jurnal Abdi Masyarakat Humanis, 1(1).

https://www.ditjenmiltun.net/index.php?o ption $=$ com content $\&$ view $=$ article $\&$ id $=32$ 63:materi-sosialisasi-peraturan- mahkamah-agung-ri-tentang-

administrasi-perkara-dan-persidangan-dipengadilan-secara-elektronik-dan-materitot-fitur-e-litigasi-pada-aplikasi-ecourt\&catid=114:umum

\section{DOKUMENTASI KEGIATAN}
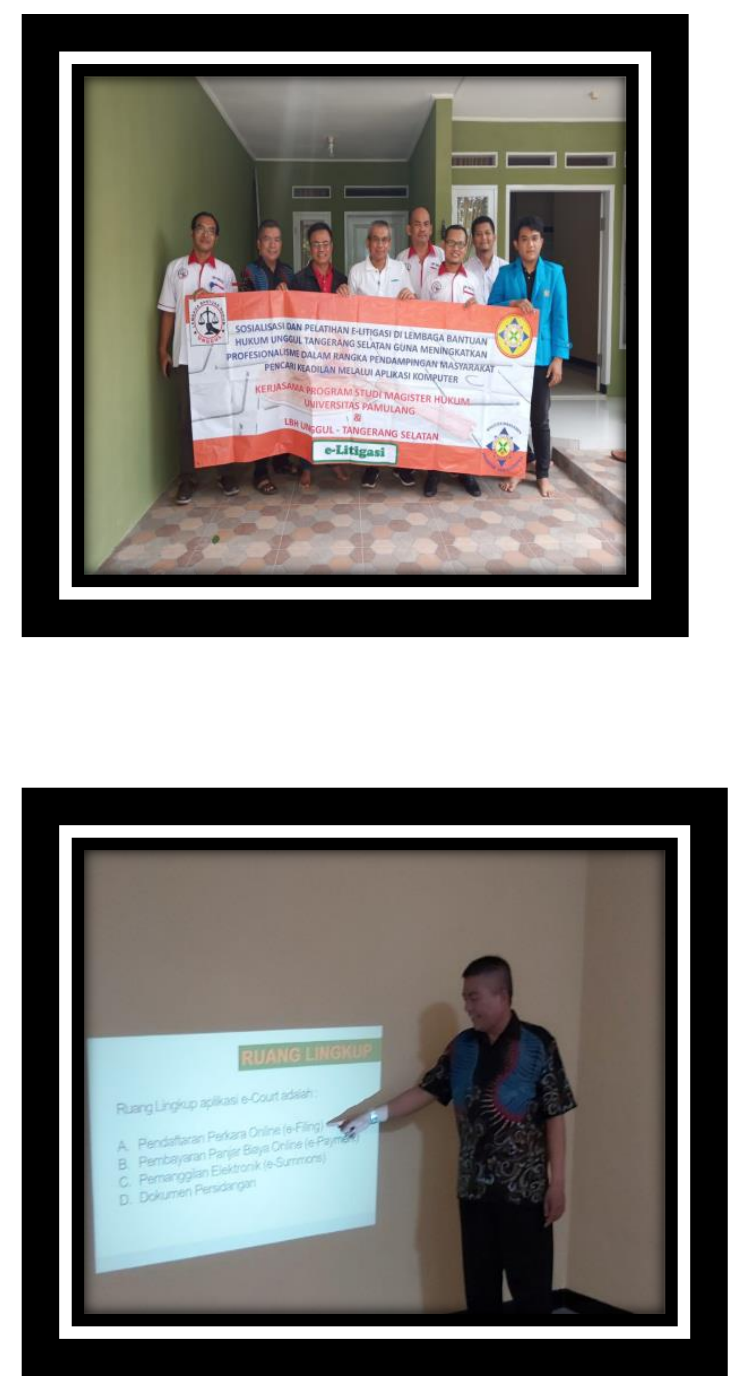


\begin{tabular}{|c|c|}
\hline JURNAL ABDIMAS & 5-6849, E-ISSN 2716-070X \\
\hline 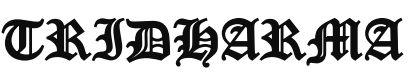 & Jurn \\
\hline AtA & dimasjurnal.unpam@gmail.com Telp: (021) 741-25 \\
\hline
\end{tabular}
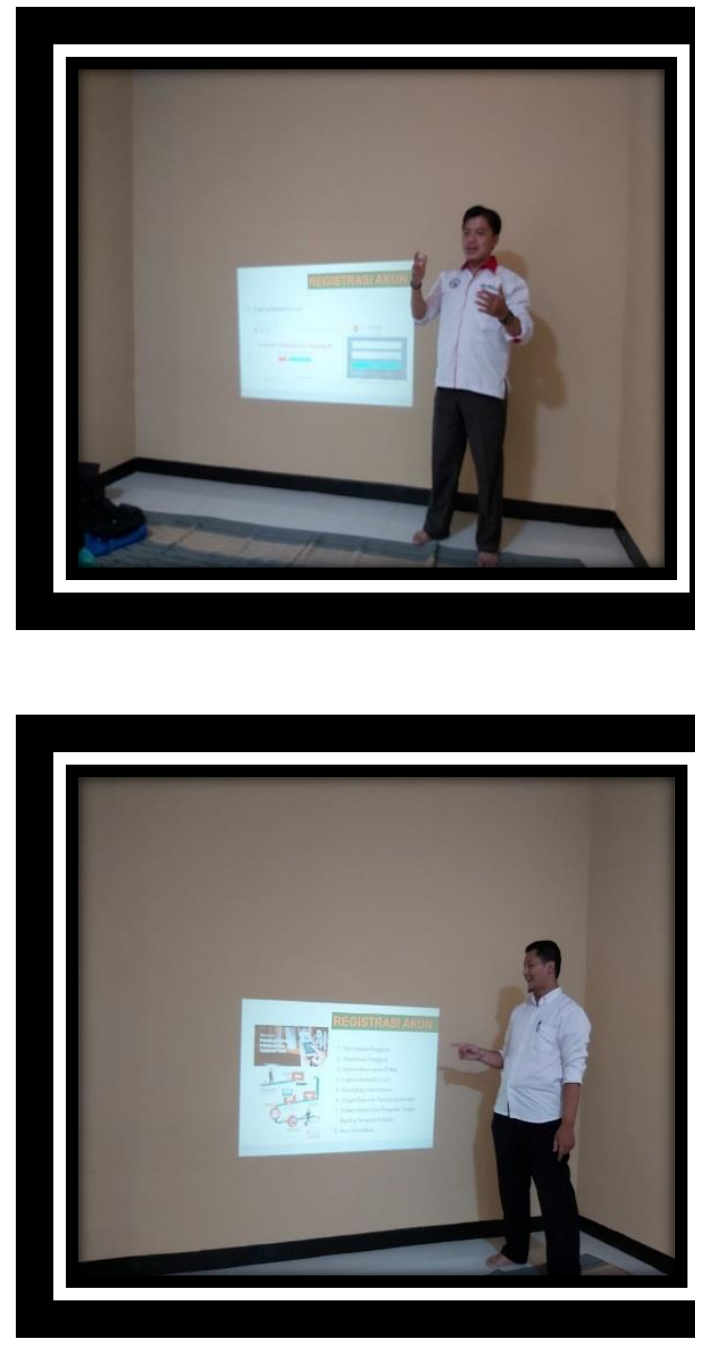